\title{
Chromite as a lithochemical tracer mineral in Finnish mafic- ultramafic host lithologies
}

\author{
M. A. Aaltonen*, C. Beier, A. Abersteiner and A. Heinonen \\ Department of Geosciences and Geography, University of Helsinki, Helsinki, Finland \\ *Corresponding author e-mail: milla.aaltonen@helsinki.fi
}

\begin{abstract}
Summary This research project targets the utilization of chromite as a lithochemical tracer to identify $\mathrm{Ni}$-Cu-PGE deposits in mafic-ultramafic lithologies. We use detailed in-situ geochemical methods to constrain the trace element and PGE distribution in Finnish greenstone belt and ophiolite chromites, which have crystallized in different sulfide saturation conditions, and have been subjected to metamorphism to varying degrees. Our preliminary results reveal that the chromite cores have maintained the original magma composition at least partially, while the crystal rims generally reflect post-magmatic processes. Our findings suggest that with careful consideration, chromite can be used as a lithochemical tracer of magmatic processes even in highly metamorphosed terrains.
\end{abstract}

\section{Introduction and background to current research}

The chromite mineral group commonly occurs in mantle derived mafic-ultramafic lithologies and its composition yields insights into Ni-Cu-PGE ore-forming processes. Recently, attention has been focused to the contents of the platinum group elements (PGEs; Rh, Ru, Ir, Os, Pd, Pt) in chromite. Previous studies suggest that the Ru content of chromite can fingerprint sulfide saturation processes of the host magma in mafic-ultramafic systems (Fiorentini et al. 2008, Locmelis et al. 2018). In sulfide-saturated conditions, chalcophile PGEs partition strongly into the immiscible sulfide phase, but in sulfide-undersaturated conditions Ru-rich chromite can crystallize (Fiorentini et al. 2008, Brenan et al. 2012). However, post-magmatic processes can overprint the magmatic geochemical signatures (including PGEs), which makes it challenging to discriminate primary compositions from secondary compositions, especially in dominantly metamorphosed terrains such as Fennoscandia. In addition, studies covering systematic mineral-scale variations in trace element (Ti, V, Mn, Co, Ni, Zn) and PGE concentrations in altered and unaltered chromites are rare (e.g., Mukherjee et al. 2015).

We study the distribution of major and trace elements and PGEs of some Finnish chromites from mineralized (S-saturated) and barren (S-undersaturated) greenstone belt and ophiolite lithologies. We perform in-situ core to rim analyses on altered and unaltered chromite grains to monitor whether the chromite mineral chemistry reflects the changes in sulfide saturation conditions of a system in crystal to regional scale, and to what extent metamorphism has overprinted the magmatic signatures.

\section{Results and discussion}

The preliminary LA-ICP-MS results of the greenstone belt and ophiolite chromites $(\mathrm{n}=58)$ show distinct chromite chemistries between the two lithologies and between the mineral cores and rims. The ophiolite chromites have distinctly higher $\mathrm{Mg \#}[\mathrm{Mg} /(\mathrm{Mg}+\mathrm{Fe})]$ and lower $\mathrm{Cr} \#$ [Cr/(Cr+Al)], $\mathrm{Zn} / \mathrm{Al}, \mathrm{Ru} / \mathrm{Al}$, and $\mathrm{Mn} / \mathrm{Al}$ (Fig. 1, 2) compared to the greenstone belt chromites. Generally, the greenstone chromites show systematic core to rim increase in $\mathrm{Cr} \#, \mathrm{Mn} / \mathrm{Al}, \mathrm{V} / \mathrm{Al}$, $\mathrm{Zn} / \mathrm{Al}$, and $\mathrm{Ru} / \mathrm{Al}$ (Fig. 1, 2). Our preliminary dataset is not yet standardized with external major element data, but the elemental ratios still yield crucial information on the elemental distribution. 
The core to rim enrichment of fluid mobile elements relative to the Al concentrations $(\mathrm{Zn} / \mathrm{Al}, \mathrm{Mn} / \mathrm{Al}, \mathrm{V} / \mathrm{Al})$ implies a progressing elemental exchange with fluids at the crystal rims. We note here that the distinct lithologies display different ratios of fluid mobile/immobile elements suggesting that they reflect different fluid compositions. The chromite cores have instead retained the primary magmatic composition, at least moderately. Hence, the preliminary results indicate that even in the highly metamorphosed Finnish terrains, the chromite core composition can be used to trace primary igneous processes while the chromite rim compositions may give insights to post-magmatic processes, such as fluid activity and composition.

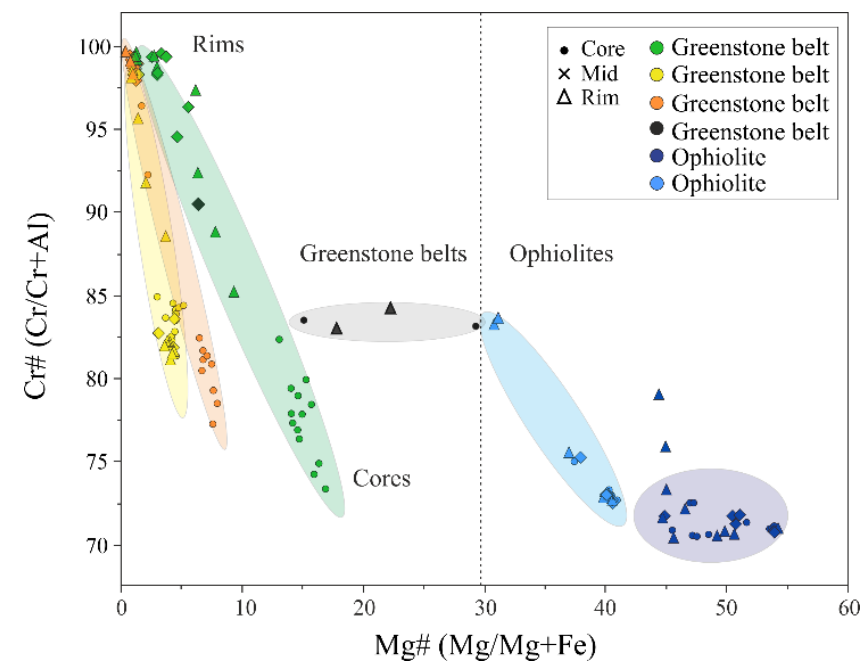

Figure 12. The preliminary core to rim results of the Finnish greenstone belt and ophiolite chromites. $\mathrm{Mg} \#=[\mathrm{Mg} /(\mathrm{Mg}+\mathrm{Fe})]$ and $\mathrm{Cr} \#=[\mathrm{Cr} /(\mathrm{Cr}+\mathrm{Al})]$. The dataset is not yet standardized with external major element data.
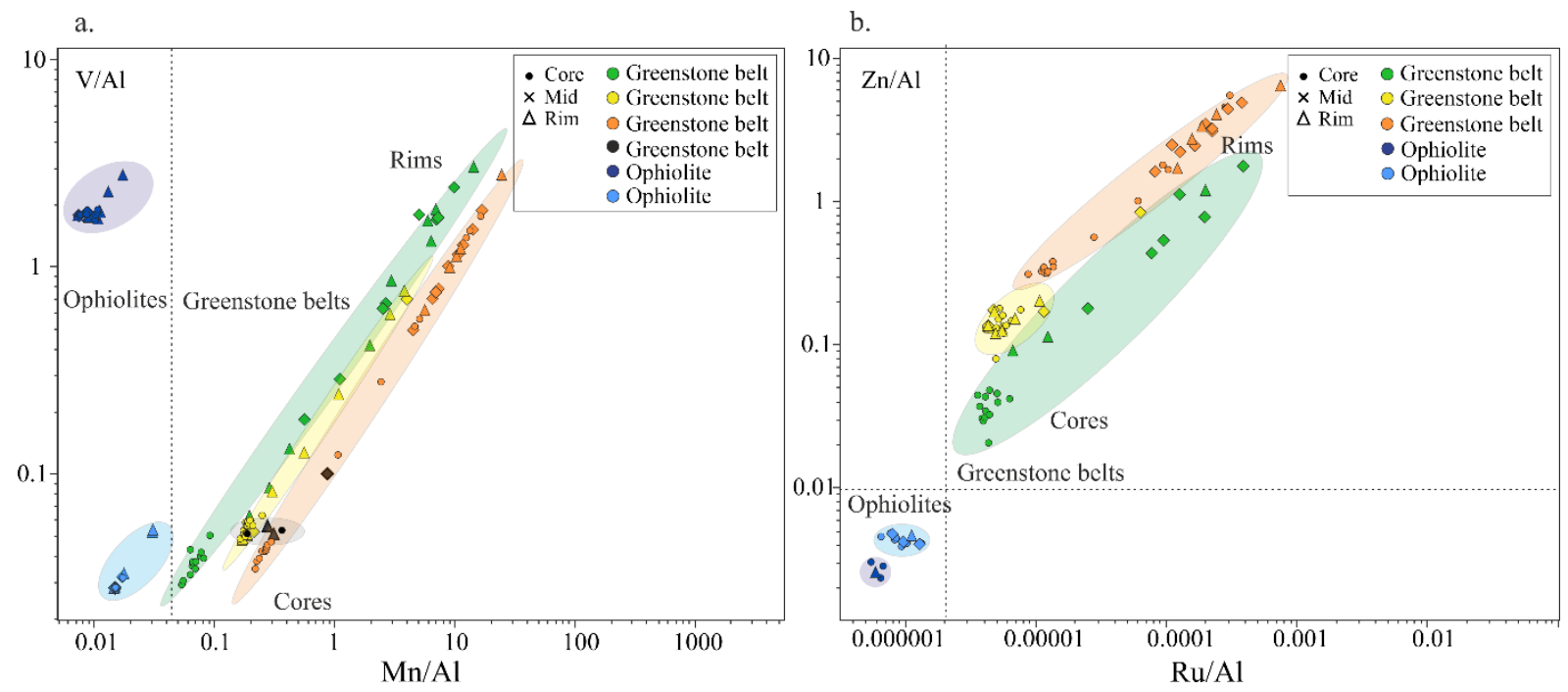

Figure 2. The preliminary core to rim results of the Finnish greenstone belt and ophiolite chromites. $\mathrm{Mn} / \mathrm{Al}$ vs. V/Al (a.) and $\mathrm{Ru} / \mathrm{Al}$ vs. $\mathrm{Zn} / \mathrm{Al}$ (b.) of the analysed chromites expressed in logarithmic scale. The dataset is not yet standardized with external major element data.

\section{Future prospects}


The sample set will be extended to cover chromites from other Finnish lithologies and from the Macquarie Island (Southwestern Pacific) and the Troodos ophiolites (Cyprus). The aim is to establish a comprehensive chromite composition database covering various sulphide-bearing and barren lithologies. The database will provide information on the magmatic, metamorphic, and hydrothermal evolution involved in the ore-forming processes and will help to identify potential $\mathrm{Ni}-\mathrm{Cu}-\mathrm{PGE}$ ore bodies. The ultimate goal of our project is to evaluate the potential of chromite as a lithochemical tracer mineral establishing a global database, in addition to identifying the variables that influence the mineral chemistry of chromites.

\section{Acknowledgements}

We thank Petri Peltonen (University of Helsinki) for organizing the samples and Tapio Halkoaho with other personnel from the Geological Survey of Finland (Kuopio) for kindly providing the samples used and presented in this study.

\section{References:}

Brenan JM, Finnigan CF, McDonough WF, Homolova V (2012) Experimental constraints on the partitioning of $\mathrm{Ru}, \mathrm{Rh}, \mathrm{Ir}, \mathrm{Pt}$ and Pd between chromite and silicate melt: The importance of ferric iron. Chem. Geol. 302303:16-32.

Fiorentini ML, Beresford SW, Barley ME (2008) Ruthenium-Chromium variation: a new lithochemical tool in the exploration for komatiite-hosted Ni-Cu-(PGE) deposits. Econ. Geol. 103:431-437.

Locmelis M, Fiorentini M, Barnes SJ, Hanski EJ, Kobussen AF (2018) Ruthenium in chromites as indicator for magmatic sulfide liquid equilibration in mafic-ultramafic systems. Ore Geol. Rev. 97:152-170.

Mukherjhee R, Mondal SK, González-Jiménez JM, Griffin WL, Pearson NJ, O’Reilly SY (2015) Trace-element fingerprints of chromite, magnetite and sulfides from the 3.1. Ga ultramafic-mafic rocks of the Nuggihalli greenstone belt, Western Dharwar craton (India). Contrib. Miner. Petrol. 169:59. 